\title{
Anthropogenic flank attack on polar bears: interacting consequences of climate warming and pollutant exposure
}

\author{
Bjørn M. Jenssen ${ }^{1,2 *}$, Gro D. Villanger ${ }^{3}$, Kristin M. Gabrielsen ${ }^{1}$, Jenny Bytingsvik ${ }^{4}$, Thea Bechshoft ${ }^{5}$, \\ Tomasz M. Ciesielski ${ }^{1}$, Christian Sonne ${ }^{6}$ and Rune Dietz ${ }^{6}$ \\ 1 Department of Biology, Norwegian University of Science and Technology, Trondheim, Norway \\ 2 Department of Arctic Technology, The University Centre in Svalbard, Longyearbyen, Norway \\ ${ }^{3}$ Division of Mental Health, Department of Child Development and Mental Health, Norwegian Institute of Public Health, Oslo, Norway \\ ${ }^{4}$ Akvaplan-niva AS, Fram Centre, Tromsø, Norway \\ ${ }^{5}$ Department of Biological Sciences, University of Alberta, Alberta, Canada \\ ${ }^{6}$ Department of Bioscience, Faculty of Science and Technology, Arctic Research Centre, Aarhus University, Roskilde, Denmark
}

\section{Edited by:}

Tore Haug, Institute of Marine

Research, Norway

Reviewed by:

Andrew Edward Derocher, University of Alberta, Canada

Øystein Wiig, University of Oslo,

Norway

*Correspondence:

Bjørn M. Jenssen, Department of Biology, Norwegian University of

Science and Technology,

Hegskoleringen 5,

NO-7491 Trondheim, Norway

e-mail: bjorn.munro.jenssen@ ntnu.no
Polar bears (Ursus maritimus) are subjected to several anthropogenic threats, climate warming and exposure to pollutants being two of these. For polar bears, one of the main effects of climate warming is limited access to prey, due to loss of their sea ice habitat. This will result in prolonged fasting periods and emaciation and condition related negative effects on survival and reproduction success. Prolonged fasting will result in increases of the tissue concentrations of persistent organic pollutants (POPs) in polar bears, and thus increase the probability for POP levels to exceed threshold levels for effects on health, and thus on reproductive success and survival. There are clear potentials for interactions between impacts of climate warming and impacts of pollutant exposure on polar bears. It is likely that that fasting-induced increases of POPs will add to mortality rates and decrease reproductive success beyond effects caused by loss of habitat alone. However, there is a lack of studies that have addressed this. Thus, there is a need to focus on population effects of POP exposure in polar bears, and to consider such effects in relation to the effects of climate induced habitat loss.

Keywords: arctic, pollution and global change, PCBs, ecology, climate change impacts

\section{POLAR BEARS, CLIMATE WARMING, AND POLLUTION EXPOSURE}

Polar bears (Ursus maritimus) have received considerable focus as a wildlife species impacted by climate change since projected sea ice loss is argued to restrict their access to seals on the ice, making their survival of global concern (Durner et al., 2009; Edwards et al., 2011; Molnar et al., 2011; Stirling and Derocher, 2012; Derocher et al., 2013). The polar bear is the single species among mammals and birds listed under the U.S. Endangered Species Act that attracts most public attention (Roberge, 2014), and a symbol-species of the potential devastating effects of global climate change on biodiversity and ecosystems. Modeling has shown that the southernmost polar bear populations are those that are most vulnerable, and will struggle to persist there throughout this century (Castro De La Guardia et al., 2013). Models have also predicted losses of polar bear sea ice habitats in the polar basin during this century (Durner et al., 2009) and indicated that twothird of the world's polar bears could disappear if greenhouse gas emissions continue as predicted (Amstrup et al., 2008).

However, climate warming is not the only anthropogenic factor that affects polar bear populations. Exposure to pollutants, hunting and increase in ecotourism and raw material exploration and exploitation are other major anthropogenic threats to this species (IUCN, 2014). Because of their high tropic position and food web biomagnification of persistent organic pollutants
(POPs), and mercury (Hg), polar bears are exposed to high levels of these harmful compounds (Letcher et al., 2010; Sonne, 2010). Due to international regulations on production and use of POPs (www.pops.int) there have been significant decreases in levels of the conventional POPs in polar bears and their prey during the last decades, whereas brominated flame retardants (BFRs) and perfluoroalkyl substances (PFASs) overall have increased over the same period although some have started to decline in recent years (Bytingsvik et al., 2012a,b; Dietz et al., 2013c; Dietz R Rigét et al., 2013b; Riget et al., 2013). However, levels of most POPs such as polychlorinated biphenyls (PCBs), brominated flame retardants (BFRs), organochlorinated pesticides (OCPs) and perfluoroalkyl compounds (PFASs), are still high in polar bears, and often above threshold levels for physiological and toxicological effects reported in the literature for mammals (Letcher et al., 2010; Sonne, 2010). Furthermore, levels of $\mathrm{Hg}$ have been shown to increase in polar bears (Dietz et al., 2011) and there are increased concerns about the effects of metabolites produced by endogenous biotransformation of POPs (Letcher et al., 2010).

Many POPs and their metabolites, as well as mercury $(\mathrm{Hg})$ have been shown to have endocrine disruptive effects, and are thus classified as endocrine disrupting chemicals (EDCs) (Colborn, 2004). In general, the endocrine system together with the nervous and the immune systems, form the main regulatory mechanisms in the animal body controlling all vital functions 
(Lintelmann et al., 2003). Many POPs also interfere with immune function, lipid storage and metabolism and reproduction, and may perturb important processes during early growth and development (Letcher et al., 2010). There are concerns that effects on organisms caused by climate change and contaminant exposure interact, thus causing combined effects that may have largescale ecological impacts (Jenssen, 2006; Schiedek et al., 2007; Wingfield, 2008; Noyes et al., 2009; Unep/Amap, 2011; Moe et al., 2013). The combined effects of these two anthropogenic factors on populations and ecosystems may be additive, or even synergistic. Herein, we focus on how POPs may interact with, and possibly enhance the effects of climate warming in polar bears. Insight into such combined effects caused by these two major anthropogenic stressors provides perspectives that are of importance for research and for conservation management of the species.

\section{COMBINED EFFECTS ON ENERGETIC PROCESSES}

In some regions periods of open-water force polar bears onshore during summer and autumn, and thus limit access to their most common high-energy containing prey, that mainly are ringed seals (Pusa hispida) (Stirling and Derocher, 2012; Derocher et al., 2013). During these periods they fast and rely on body lipid reserves for energy (Cherry et al., 2009). Climate warming causes earlier break-up of sea-ice and thus prolongs this fasting period in polar bears, resulting in increased mortality rates due to emaciation and starvation (Gagnon and Gough, 2005; Molnar et al., 2010, 2014; Stirling and Derocher, 2012). Because many lipid-soluble POPs are not excreted, fasting and especially emaciation will cause large increases of the concentrations of these compounds in blood and target tissues (Polischuk et al., 2002; Christensen et al., 2007; Helgason et al., 2013). Thus, prolonged fasting due to climate induced ice-loss and resultant lowered prey availability increases the likelihood for POPs levels to exceed threshold levels for effects. Many POPs have health effects that directly affect survival rates, such as their negative effects on the immune system (Vos et al., 2000). Thus, it is likely that fasting-induced increases of these compounds will increase the mortality rates beyond those predicted to be caused by the climate-induced prolonged fasting period alone (Molnar et al., 2010, 2014). It is also likely that fasting-induced increases of burdens of POPs that are reproductive EDCs will add to the predicted negative reproductive effects that lower body condition alone has on reproductive success of polar bears (Regehr et al., 2010); Figure 1.

It is suggested that decreases of polar bear sea ice habitats will result in increased movement and migration rates and distances to remain on ice (Derocher et al., 2004; Durner et al., 2009), thus causing increased energetic requirements and feeding rates. In female polar bears it has been suggested that high movement rates and distances associated with occupying large home range sizes may result in high blood concentrations of PCBs (Olsen et al., 2003). This is because the high activity level associated with occupying large home range sizes requires high food intake, which causes high dietary intake of these persistent compounds (Olsen et al., 2003). It is therefore possible that long-range annual migrations mitigated by sea ice habitat

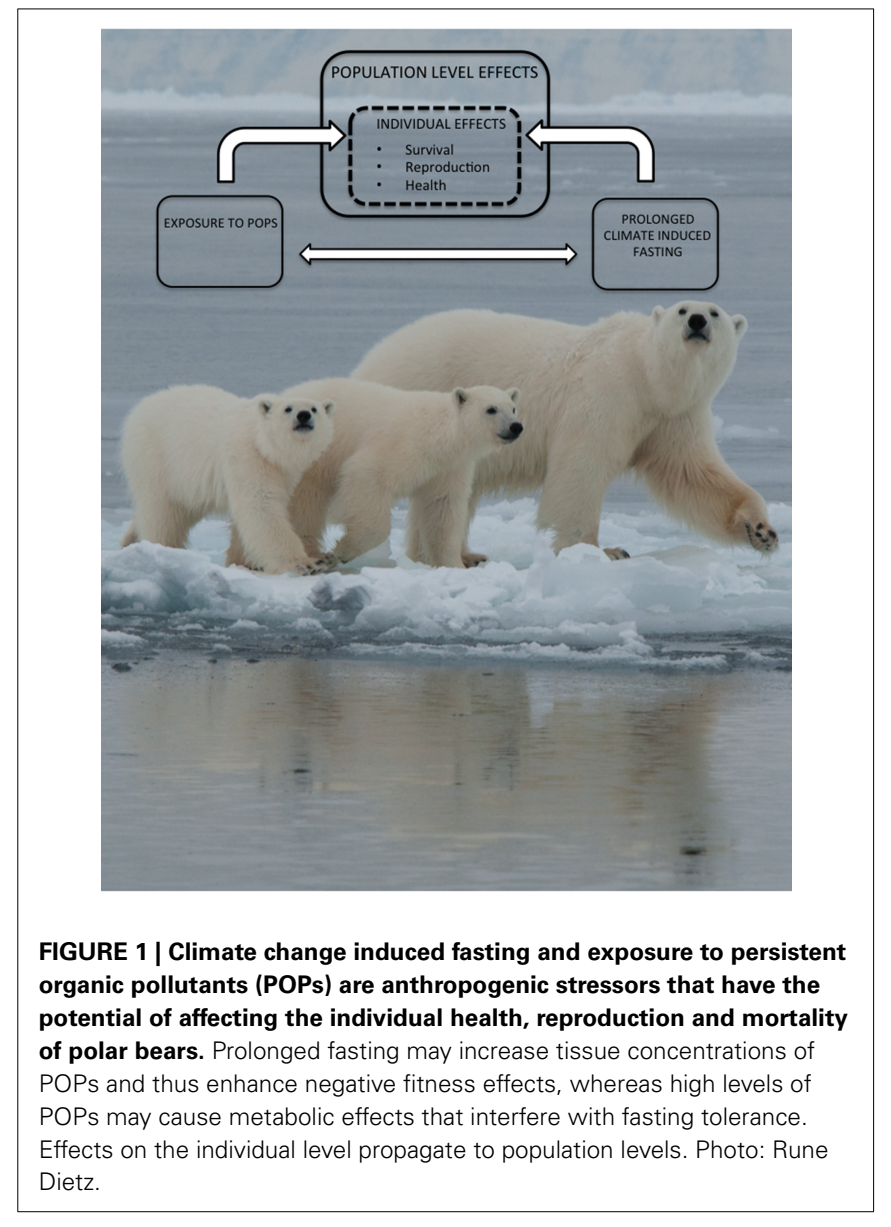

loss will result in increased uptake and accumulation of POPs due to the increased feeding demands needed for longer migrations. In some regions, decline of sea ice extension has resulted in changes in the presence of seal species that polar bears depredate, and this has been shown to cause increased bioaccumulation of certain POPs (Thiemann et al., 2008; McKinney et al., 2009, 2013). Dietary shift toward feeding on plants, berries and caribou (Rangifer tarandus) and seabird eggs, respectively (Ramsay and Hobson, 1991; Gormezano and Rockwell, 2013a,b; Iles et al., 2013; Iverson et al., 2014), will most likely decrease and increase, respectively, the dietary uptake of POPs. Furthermore, climate warming induced immigrating warm-adapted fish species (Valdimarsson et al., 2012; Mackenzie et al., 2014) may act as biovectors that increases contaminant levels in marine arctic ecosystems (Macdonald et al., 2005; Carrie et al., 2010), ultimately causing increased bioaccumulation of these compounds in polar bears.

In polar bears, the thyroid hormone system is sensitive to the effects of several POPs (Skaare et al., 2001; Braathen et al., 2004; Gutleb et al., 2010; Knott et al., 2011; Villanger et al., 2011; Bytingsvik et al., 2013; Simon et al., 2013; Gabrielsen et al., 2015). The effects of EDCs on thyroid hormones appear to be particularly pronounced in female and subadult polar bears, whereas adult males appear to be much more resistant (Braathen et al., 2004; Villanger et al., 2011). In polar bears there are also 
indications that concentrations of T4 in muscle tissue and deiodinase activities in muscle, kidney and liver are influenced by circulating concentrations of POPs (Gabrielsen et al., 2015). Since thyroid hormones are involved in nearly all metabolic pathways (McNabb, 1995), EDC induced thyroid disruption may seriously interfere with energy expenditure during fasting. Thyroid dysfunction has also been linked to reduced fertility, increased rates of spontaneous abortion, premature delivery and low birth weight (Krassas et al., 2010). Because climate driven fasting and emaciation will increase contaminant loads in target tissues, the thyroid related effects might become "self-reinforcing" and thus escalate the negative effects on survival and reproduction.

The glucocorticoid endocrine system also plays an important role in metabolism and energetic processes (Hiller-Sturmhöfel and Bartke, 1998). In polar bears, the main glucocorticoid hormone in mammals, cortisol, has been reported to be influenced by plasma concentrations of pesticides and PCBs (Oskam et al., 2004; Bechshøft et al., 2012). Cortisol in polar bears is also influenced by climate conditions, indicating that the bears are under higher levels of physiological stress during years with less ice cover and thus less easy access to seals (Bechshøft et al., 2013). Pollutant exposure may thus add to the physiological stress encountered by polar bears during years with low ice coverage, enhancing the effects of climate warming.

Polar bears have an enrichment of genes associated with adipose tissue development that may be important in the adaptation to their lipid-rich diet and high blood concentrations of cholesterol and low-density lipoproteins (Liu et al., 2014). Recently, there has been an increased focus on the role of POPs on development of obesity in humans (Hotchkiss et al., 2008; Dirinck et al., 2013; De Cock and Van De Bor, 2014; Donat-Vargas et al., 2014). One mechanism for this effect may be that POPs causes "leptin-resistance" in adipose tissue, a typical metabolic alteration related to obesity (Ferrante et al., 2014). Furthermore, dietary exposure to PCBs may result in increased metabolic rates (Voltura and French, 2000). Since lipid storage and metabolism are important environmental adaptations in polar bears, disruption of these processes by POPs may seriously inflict on the ability of polar bears to tolerate prolonged fasting periods that are predicted to be associated with climate warming. If POPs increases metabolic rates, high body burdens of POPs are likely to induce higher rates of body mass loss, and thus increase mortality rates beyond those predicted to be caused by prolonged fasting alone (Molnar et al., 2010, 2014); Figure 1.

\section{COMBINED EFFECTS ON REPRODUCTION AND IMMUNITY}

Several POPs have been documented to have harmful effects on reproductive organs and hormones, and to adversely affect fertility and fecundity in mammals (Vos et al., 2000). In polar bears, POPs have been reported to affect reproductive hormones (Haave et al., 2003; Oskam et al., 2003) and to influence the morphology of male and female reproductive organs such as testicles, penis, uteri and ovary (Sonne et al., 2006). This may reduce their reproductive success (Sonne et al., 2006; Letcher et al., 2010). These morphological changes are probably a result of both pre- and post-natal effects and the pathways being via the hypothalamicpituitary-axis likely with a thyroid cross-talk (Sonne, 2010).
Although poor recruitment in the Svalbard polar bear population has been linked to their high burdens of reproductive EDCs (Derocher et al., 2003), it not possible to fully estimate the impact from these reproductive related disruptions and pathological conditions. It is likely that fasting-induced increases in reproductive EDCs will enhance the reported negative effects on reproductive success in polar bears caused by increasing duration of the ice-free period (Regehr et al., 2010)

Climate warming increases risks of disease spreading (Harvell et al., 2002), and may induce a shift in the micro-pathogen composition toward higher virulence (Shope, 1992; Burek et al., 2008). Polar bears may therefore become exposed to health challenges that they have not previously encountered (Sonne, 2010). Many POPs are immune toxic (Vos et al., 2000) and in polar bears inverse relationships between POP concentrations and immune globulins and cellular immune responses have been reported (Bernhoft et al., 2000; Lie et al., 2004, 2005). The combination of spreading of new diseases and micro-pathogens to the Arctic caused by global warming (Harvell et al., 2002) and a weakened immune system in polar bears caused by pollutant exposure will cause combined effects that can increase mortality rates. Polar bears also have low genetic diversity in their immune system, which is consistent with a long-term exposure to low levels of pathogens and parasites (Weber et al., 2013). Thus, contaminant exposure could depress their response toward micro pathogens and diseases even further, and thereby increase mortality rates. In addition, pathogens and diseases may affect reproductive rates (Sonne, 2010). It is likely that fasting will enhance immune related effects, both due to fasting-induced increases in POPs, and due to that fasting generally is associated with immunosuppression and poorer general health conditions (Sonne, 2010).

\section{COMBINED EFFECTS ON NEUROLOGICAL PROCESSES, BEHAVIOR AND DEVELOPMENT}

POPs can cause neurobehavioral effects, such as sexual and other reproductive behaviors, activity, motivation, communication, aggression, dominance and other social behaviors, as well as learning and other cognitive abilities (Zala and Penn, 2004). Field studies of behavioral effects of POPs in polar bears are, of natural causes, difficult to conduct. However, several POPs and methylmercury reported in brain tissue of polar bears, (Greaves et al., 2012, 2013; Krey et al., 2012; Dietz et al., 2013a) are known or suspected developmental neurotoxicants in humans and experimental animals (Grandjean and Landrigan, 2006, 2014; Fonnum and Mariussen, 2009; Mariussen, 2012).

POPs might affect brain function or development through many mechanisms, such as interacting with brain neurotransmitter systems (Fonnum and Mariussen, 2009). Also, the ability of some POPs to induce epigenetic changes could present a mechanistic pathway of neurodevelopmental perturbations (Mill and Petronis, 2008; Bollati and Baccarelli, 2010; Crews, 2011). Associations between neurochemical and epigenetic biomarkers and mercury levels in brain tissue have been reported for polar bears (Basu et al., 2009; Pilsner et al., 2010; Dietz et al., 2013a). Another proposed mechanism of developmental neurotoxicity is through thyroid hormone disruption, as these hormones 
are essential during fetal and early neonatal neurodevelopment (Crofton and Zoeller, 2005; Ahmed et al., 2008). Thus, the high levels of POPs reported in 4-month old polar bear cubs (Bytingsvik et al., 2012a,b) and their associated thyroid disrupting properties in cubs (Bytingsvik et al., 2013; Simon et al., 2013) raises concern for neurodevelopmental effects in polar bears.

The relative high concentrations of several POPs reported in polar bear brains may cause adverse effects, with a possible heightened susceptibility during the more sensitive fetal and neonatal stages of brain development (Rodier, 1995; Grandjean and Landrigan, 2006). Similarly to humans, this could alter behavioral traits and reduce cognitive abilities related to memory and learning in offspring. For polar bears, this could functionally reduce, e.g., hunting skills or alter mating behavior, and thus ultimately affect reproduction and survival.

\section{COMBINED EFFECTS ON POPULATIONS, GENETICS, AND EVOLUTION}

Several studies have documented that climate induced loss of sea ice has negatively affected the long-term survival and abundance of polar bears in some subpopulations (Regehr et al., 2010; Stirling and Derocher, 2012; Bromaghin et al., 2015). In contrast, there appear to be no documentation that POPs have caused decreases in polar bear populations. However, there are numerous reports that POPs affect fitness-related variables in polar bears at the individual level (Letcher et al., 2010; Sonne, 2010). Modeling of effects of POPs at the population level is thus warranted. The effects of both POPs and climate warming will affect densitydependent processes at the population level. Thus, mortality due to POP exposure and habitat loss caused by climate warming can separately and/or combined, reduce competition for food and thus reduce starvation in surviving animals.

The divergence of polar bears from brown bears (Ursus arctos) has taken 480-340 thousand years (Edwards et al., 2011; Liu et al., 2014). It is also indicated that polar bears were adapted to arctic marine diet and life 130-110 thousand years ago (Lindqvist et al., 2010), indicating an unprecedented time for rapid evolution of less than 20,500 generations (Liu et al., 2014). Furthermore, dispersal events driven by climate fluctuations has caused opportunistic mating between these two species, suggesting that interspecific hybridization may be a mechanism by which polar bears deals with marginal habitats during previous non-anthropogenic periods of environmental deterioration (Edwards et al., 2011). The history of the large-scale environmental changes caused by anthropogenic pollution is short in relation to their evolutionary history. Whereas polar bears most likely have experienced rapid and dramatic climatic fluctuations during the past hundreds of thousand years, exposure to anthropogenic POPs have occurred for less than 100 years. Although Atlantic tomcod (Microgadus tomcod) inhabiting waters highly polluted with PCBs and dioxins, genetically evolved AhR resistance over the time-span of three decades (Wirgin et al., 2011), it is very unlikely that a similar rapid evolution will occur in a polar bears.

Morphometric differences in the size and shape of individual polar bear skulls collected in 1892-1932, which is prior to the major anthropogenic environmental changes, as compared to in skulls from 1961 to 2002 were suggested to be a combined consequence of exposure to POPs and climate induced changes in the availability of food resources (Pertoldi et al., 2009). These combined effects may also have affected the polar bears' genetic composition and effective population size (Pertoldi et al., 2009). An epigenetic study documented Hg-associated DNA hypomethylation in brain stems of male polar bears (Pilsner et al., 2010). Epigenetic responses do not represent a permanent redirection of phenotype in the same way as mutation and natural selection (Burggren and Crews, 2014), and are "turned off" in downstream generations when the environmental stressor that created them diminishes or disappears (Burggren, 2014). However, multi-generation in utero exposure to a stressor (such as $\mathrm{Hg}$ and POPs) may cause long-lasting transgenerational effects (Burggren and Crews, 2014). It should also be noted that although in mammals, epigenetic markers are erased before being reestablished, a process referred to as "reprogramming," recent studies show that some epigenetic marks escape epigenetic reprogramming (Mendizabal et al., 2014).

\section{CONCLUDING REMARKS}

According to the points discussed above, there are clear potentials for interactions between impacts of climate warming and impacts of pollutant exposure on polar bears. However, there is a lack of studies that can confirm or discard the presence of such interactions. Of particular concern are the interacting effects of the climate induced prolonged fasting periods and the resultant increased POP levels in polar bears. We hypothesize that fasting-induced increases of POPs will add to mortality rates and decrease reproductive success beyond effects caused by loss of habitat alone. When considering the numerous fitness-related traits reported to be influenced by POPs, there is a need to focus on population effects of POP exposure in polar bears, and to consider such effects in relation to the effects of habitat loss.

\section{REFERENCES}

Ahmed, O. M., El-Gareib, A. W., El-Bakry, A. M., Ei-Tawab, S. M. A., and Ahmed R. G. (2008). Thyroid hormones states and brain development interactions. Int. J. Dev. Neurosci. 26, 147-209. doi: 10.1016/j.ijdevneu.2007.09.011

Amstrup, S. C., Marcot, B. G., and Douglas, D. C. (2008). "A bayesian network modeling approach to forecasting the 21 st century worldwide status of polar bears," in Arctic Sea Ice Decline: Observations, Projections, Mechanisms, and Implications, Vol. 180, eds E. T. DeWeaver, C. M. Bitz, and L.-B. Tremblay (Washington, DC: American Geophysical Union), 213-268.

Basu, N., Scheuhammer, A. M., Sonne, C., Letcher, R. J., Born, E. W., and Dietz, R. (2009). Is Dietary mercury of neurotoxicological concern to wild polar bears (Ursus maritimus)? Environ. Toxicol. Chem. 28, 133-140. doi: 10.1897/08-251.1

Bechshøft, T. Ø., Sonne, C., Dietz, R., Born, E. W., Muir, D. C. G., Letcher, R. J., et al. (2012). Associations between complex OHC mixtures and thyroid and cortisol hormone levels in East Greenland polar bears. Environ. Res. 116, 26-35. doi: 10.1016/j.envres.2012.04.010

Bechshøft, T. O., Sonne, C., Riget, F. F., Letcher, R. J., Novak, M. A., Henchey, E., et al. (2013). Polar bear stress hormone cortisol fluctuates with the North Atlantic Oscillation climate index. Polar Biol. 36, 1525-1529. doi: 10.1007/s00300-013-1364-y

Bernhoft, A., Skaare, J. U., Wiig, Ø., Derocher, A. E., and Larsen, H. J. S. (2000). Possible immunotoxic effects of organochlorines in polar bears (Ursus maritimus) at Svalbard. J. Toxicol. Environ. Health 59A, 561-574. doi: 10.1080/0098 41000156682

Bollati, V., and Baccarelli, A. (2010). Environmental epigenetics. Heredity 105, 105-112. doi: 10.1038/hdy.2010.2 
Braathen, M., Derocher, A. E., Wiig, O., Sormo, E. G., Lie, E., Skaare, J. U., et al. (2004). Relationships between PCBs and thyroid hormones and retinol in female and male polar bears. Environ. Health Perspect. 112, 826-833. doi: 10.1289/ehp.6809

Bromaghin, J. F., McDonald, T. L., Stirling, I., Derocher, A. E., Richardson, E. S., Regehr, E. V., et al. (2015). Polar bear population dynamics in the Beaufort Sea during a period of sea ice decline. Ecol. Appl. doi: 10.1890/14-1129.1. [Epub Ahead of print].

Burggren, W. W. (2014). Epigenetics as a source of variation in comparative animal physiology_or-Lamarck is lookin' pretty good these days. J. Exp. Biol. 217, 682-689. doi: 10.1242/jeb.086132

Burggren, W. W., and Crews, D. (2014). Epigenetics in comparative biology: why should we pay attention. Int. Comp. Biol. 54, 7-20. doi: 10.1093/icb/icu013

Burek, K. A., Gulland, F. M. D., and O'Hara, T. M. (2008). Effects of climate change on Arctic marine mammal health. Ecol. Appl. 18, S126-S134. doi: 10.1890/060553.1

Bytingsvik, J., Lie, E., Aars, J., Derocher, A. E., Wiig, O., and Jenssen, B. M. (2012a). PCBs and OH-PCBs in polar bear mother-cub pairs: a comparative plasma levels in 1998 and 2008. Sci. Total. Environ. 417, 117-128. doi: 10.1016/j.scitotenv.2011.12.033

Bytingsvik, J., Simon, E., Leonards, P. E. G., Lamoree, M., Lie, E., Aars, J., et al. (2013). Transthyretin-binding activity of contaminants in blood from polar bear (Ursus maritimus) cubs. Environ. Sci. Technol. 47, 4778-4786. doi: $10.1021 /$ es305160v

Bytingsvik, J., Van Leeuwen, S. P. J., Hamers, T., Swart, K., Aars, J., Lie, E., et al. (2012b). Perfluoroalkyl substances in polar bear mother-cub pairs: a comparative study based on plasma levels from 1998 and 2008. Environ. Int. 49, 92-99. doi: 10.1016/j.envint.2012.08.004

Carrie, J., Wang, F., Sanei, H., Macdonald, R. W., Outridge, P. M., and Stern, G. A. (2010). Increasing contaminant burdens in an arctic fish, burbot (Lota lota), in a warming climate. Environ. Sci. Technol. 44, 316-322. doi: 10.1021/es902582y

Castro De La Guardia, L., Derocher, A. E., Myers, P. G., Terwisscha Van Scheltinga, A. D., and Lunn, N. J. (2013). Future sea ice conditions in Western Hudson Bay and consequences for polar bears in the 21st century. Glob. Change Biol. 19, 2675-2687. doi: 10.1111/gcb.12272

Cherry, S. G., Derocher, A. E., Stirling, I., and Richardson, E. S. (2009). Fasting physiology of polar bears in relation to environmental change and breeding behavior in the Beaufort Sea. Polar Biol. 32, 383-391. doi: 10.1007/s00300-0080530-0

Christensen, J. R., Macduffee, M., Yunker, M. B., and Ross, P. S. (2007). Hibernation-associated changes in persistent organic pollutant (POP) levels and patterns in British Columbia grizzly bears (Ursus arctos horribilis). Environ. Sci. Technol. 41, 1834-1840. doi: 10.1021/es0626335

Colborn, T. (2004). Neurodevelopment and endocrine disruption. Environ. Health Perspect. 112, 944-949. doi: 10.1289/ehp.6601

Crews, D. (2011). Epigenetic modifications of brain and behavior: theory and practice. Horm. Behav. 59, 393-398. doi: 10.1016/j.yhbeh.2010.07.001

Crofton, K. M., and Zoeller, R. T. (2005). Mode of action: neurotoxicity induced by thyroid hormone disruption during development-hearing loss resulting from exposure to PHAHs. Crit. Rev. Toxicol. 35, 757-769. doi: 10.1080/10408440591007304

De Cock, M., and Van De Bor, M. (2014). Obesogenic effects of endocrine disruptors, what do we know from animal and human studies? Environ. Int. 70, 15-24. doi: 10.1016/j.envint.2014.04.022

Derocher, A. E., Aars, J., Amstrup, S. C., Cutting, A., Lunn, N. J., Molnar, P. K., et al. (2013). Rapid ecosystem change and polar bear conservation. Conserv. Lett. 6, 368-375. doi: 10.1111/conl.12009

Derocher, A. E., Lunn, N. J., and Stirling, I. (2004). Polar bears in a warming climate. Integr. Comp. Biol. 44, 163-176. doi: 10.1093/icb/44.2.163

Derocher, A. E., Wolkers, H., Colborn, T., Schlabach, M., Larsen, T. S., and Wiig, O. (2003). Contaminants in Svalbard polar bear samples archived since 1967 and possible population level effects. Sci. Total. Environ. 301, 163-174. doi: 10.1016/S0048-9697(02)00303-0

Dietz, R., Born, E. W., Riget, F. F., Aubail, A., Sonne, C., Drimmei, R. C., et al. (2011). Temporal trends and future predictions of mercury concentrations in northwest Greenland polar bears (Ursus maritimus). Environ. Sci. Technol. 45, 1458-1465. doi: 10.1021/es1028734

Dietz, R, Rigét, F. F., Sonne, C., Born, E. W., Bechshøft, T., McKinney, M. A., et al. (2013b). Part 1: three decades (1984-2010) of legacy contaminant trends in
East Greenland polar bears (Ursus maritimus). Environ. Int. 59, 485-493. doi: 10.1016/j.envint.2012.09.004

Dietz, R., Rigét, F. F., Sonne, C., Born, E. W., Bechshøft, T., McKinney, M. A., et al. (2013c). Part 2: three decades (1984-2010) of flame retardant trends in East Greenland polar bears (Ursus maritimus). Environ. Int. 59, 494-500. doi: 10.1016/j.envint.2012.09.008

Dietz, R., Sonne, C., Basu, N., Braune, B., O’Hara, T., Letcher, R. J., et al. (2013a) What are the toxicological effects of mercury in Arctic biota? Sci. Total. Environ. 443, 775-790. doi: 10.1016/j.scitotenv.2012.11.046

Dirinck, E., Covaci, A., Van Gaal, L., and Verhulst, S. (2013). Obesity. Oxford: Blackwell Science Publ, Osney Mead.

Donat-Vargas, C., Gea, A., Sayon-Orea, C., Carlos, S., Martinez-Gonzalez, M. A., and Bes-Rastrollo, M. (2014). Association between dietary intakes of PCBs and the risk of obesity: the SUN project. J. Epidemiol. Commun. Health 68, 834-841. doi: 10.1136/jech-2013-203752

Durner, G. M., Douglas, D. C., Nielson, R. M., Amstrup, S. C., McDonald, T. L., Stirling, I., et al. (2009). Predicting 21st-century polar bear habitat distribution from global climate models. Ecol. Monogr. 79, 25-58. doi: 10.1890/07-2089.1

Edwards, C. J., Suchard, M. A., Lemey, P., Welch, J. J., Barnes, I., Fulton, T. L., et al. (2011). Ancient hybridization and an irish origin for the modern polar bear matriline. Curr. Biol. 21, 1251-1258. doi: 10.1016/j.cub.2011.05.058

Ferrante, M. C., Amero, P., Santoro, A., Monnolo, A., Simeoli, R., Di Guida, F., et al. (2014). Polychlorinated biphenyls (PCB 101, PCB 153 and PCB 180) alter leptin signaling and lipid metabolism in differentiated 3T3-L1 adipocytes. Toxicol. Appl. Pharmacol. 279, 401-408. doi: 10.1016/j.taap.2014.06.016

Fonnum, F., and Mariussen, E. (2009). Mechanisms involved in the neurotoxic effects of environmental toxicants such as polychlorinated biphenyls and brominated flame retardants. J. Neurochem. 111, 1327-1347. doi: 10.1111/j.14714159.2009.06427.x

Gabrielsen, K. M., Krokstad, J. S., Villanger, G. D., Blair, D. A. D., Obregon, M.-J., Sonne, C., et al. (2015). Thyroid hormones and deiodinase activity in plasma and tissues in relation to high levels of organohalogen contaminants in East Greenland polar bears (Ursus maritimus). Environ. Res. 136, 413-423. doi: 10.1016/j.envres.2014.09.019

Gagnon, A. S., and Gough, W. A. (2005). Trends in the dates of ice freeze-up and breakup over Hudson Bay, Canada. Arctic 58, 370-382. doi: 10.14430/arctic451

Gormezano, L. J., and Rockwell, R. F. (2013a). Dietary composition and spatial patterns of polar bear foraging on land in western Hudson Bay. BMC Ecol. 13:51. doi: 10.1186/1472-6785-13-51

Gormezano, L. J., and Rockwell, R. F. (2013b). What to eat now? shifts in polar bear diet during the ice-free season in western Hudson Bay. Ecol. Evol. 3, 3509-3523. doi: $10.1002 /$ ece 3.740

Grandjean, P., and Landrigan, P. J. (2006). Developmental neurotoxicity of industrial chemicals. Lancet 368, 2167-2178. doi: 10.1016/S0140-6736(06)69665-7

Grandjean, P., and Landrigan, P. J. (2014). Neurobehavioural effects of developmental toxicity. Lancet Neurol. 13, 330-338. doi: 10.1016/S14744422(13)70278-3

Greaves, A. K., Letcher, R. J., Sonne, C., and Dietz, R. (2013). Brain region distribution and patterns of bioaccumulative perfluoroalkyl carboxylates and sulfonates in east greenland polar bears (Ursus maritimus). Environ. Toxicol. Chem. 32, 713-722. doi: 10.1002/etc. 2107

Greaves, A. K., Letcher, R. J., Sonne, C., Dietz, R., and Born, E. W. (2012). Tissue-specific concentrations and patterns of perfluoroalkyl carboxylates and sulfonates in east Greenland polar bears. Environ. Sci. Technol. 46, 11575-11583. doi: 10.1021/es303400f

Gutleb, A. C., Cenijn, P., Van Velzen, M., Lie, E., Ropstad, E., Skaare, J. U., et al. (2010). In vitro assay shows that PCB metabolites completely saturate thyroid hormone transport capacity in blood of wild polar bears (Ursus maritimus). Environ. Sci. Technol. 44, 3149-3154. doi: 10.1021/es903029j

Haave, M., Ropstad, E., Derocher, A. E., Lie, E., Dahl, E., Wiig, O., et al. (2003). Polychlorinated biphenyls and reproductive hormones in female polar bears at Svalbard. Environ. Health Perspect. 111, 431-436. doi: 10.1289/ehp.5553

Harvell, C. D., Mitchell, C. E., Ward, J. R., Altizer, S., Dobson, A. P., Ostfeld, R. S., et al. (2002). Ecology-Climate warming and disease risks for terrestrial and marine biota. Science 296, 2158-2162. doi: 10.1126/science.1063699

Helgason, L. B., Wolkers, H., Fuglei, E., Ahlstrom, O., Muir, D., and Jorgensen, E. H. (2013). Seasonal emaciation causes tissue redistribution and an increased potential for toxicity of lipophilic pollutants in farmed arctic fox (Vulpes lagopus). Environ. Toxicol. Chem. 32, 1784-1792. doi: 10.1002/etc.2241 
Hiller-Sturmhöfel, S., and Bartke, A. (1998). The endocrine system: an overview. Alcohol. Health Res. World 22, 153-164.

Hotchkiss, A. K., Rider, C. V., Blystone, C. R., Wilson, V. S., Hartig, P. C., Ankley, G. T., et al. (2008). Fifteen years after "Wingspread"—environmental endocrine disrupters and human and wildlife health: where we are today and where we need to go. Toxicol. Sci. 105, 235-259. doi: 10.1093/toxsci/kfn030

Iles, D. T., Peterson, S. L., Gormezano, L. J., Koons, D. N., and Rockwell, R. F. (2013). Terrestrial predation by polar bears: not just a wild goose chase. Polar Biol. 36, 1373-1379. doi: 10.1007/s00300-013-1341-5

Iverson, S. A., Gilchrist, H. G., Smith, P. A., Gaston, A. J., and Forbes, M. R. (2014). Longer ice-free seasons increase the risk of nest depredation by polar bears for colonial breeding birds in the Canadian Arctic. Proc. R. Soc. B Biol. Sci. 281, 9. doi: $10.1098 /$ rspb.2013.3128

IUCN. (2014). International Union for Conservation of Nature. IUCN Red List of threatened species. Version 2014.3. IUCN, Species Survival Commission, Gland, Switzerland. Available online at: http://www.iucnredlist.org

Jenssen, B. M. (2006). Endocrine disrupting chemicals and climate change: a worst case combination for Arctic marine mammals and seabirds? Environ. Health. Perspect. 114, 76-80. doi: 10.1289/ehp.8057

Knott, K. K., Schenk, P., Beyerlein, S., Boyd, D., Ylitalo, G. M., and O'Hara, T. M. (2011). Blood-based biomarkers of selenium and thyroid status indicate possible adverse biological effects of mercury and polychlorinated biphenyls in Southern Beaufort Sea polar bears. Environ. Res. 111, 1124-1136. doi: 10.1016/j.envres.2011.08.009

Krassas, G. E., Poppe, K., and Glinoer, D. (2010). Thyroid function and human reproductive health. Endocr. Rev. 31, 702-755. doi: 10.1210/er.2009-0041

Krey, A., Kwan, M., and Chan, H. M. (2012). Mercury speciation in brain tissue of polar bears (Ursus maritimus) from the Canadian Arctic. Environ. Res. 114, 24-30. doi: 10.1016/j.envres.2012.01.006

Letcher, R. J., Bustnes, J. O., Dietz, R., Jenssen, B. M., Jorgensen, E. H., Sonne, C., et al. (2010). Exposure and effects assessment of persistent organohalogen contaminants in arctic wildlife and fish. Sci. Total. Environ. 408, 2995-3043. doi: 10.1016/j.scitotenv.2009.10.038

Lie, E., Larsen, H. J. S., Larsen, S., Johansen, G. M., Derocher, A. E., Lunn, N. J., et al. (2004). Does high organochlorine (OC) exposure impair the resistance to infection in polar bears (Ursus maritimus)? Part I: effect of OCs on the humoral immunity. J. Toxicol. Environ. Health 67A, 555-582. doi: $10.1080 / 15287390490425597$

Lie, E., Larsen, H. J. S., Larsen, S., Johansen, G. M., Derocher, A. E., Lunn, N. J., et al. (2005). Does high organochlorine (OC) exposure impair the resistance to infection in polar bears (Ursus maritimus)? Part II: possible effect of OCs on mitogen- and antigen-induced lymphocyte proliferation. J. Toxicol. Environ. Health 68A, 457-484. doi: 10.1080/15287390590903685

Lindqvist, C., Schuster, S. C., Sun, Y. Z., Talbot, S. L., Qi, J., Ratan, A., et al. (2010). Complete mitochondrial genome of a Pleistocene jawbone unveils the origin of polar bear. Proc. Natl. Acad. Sci. U.S.A. 107, 5053-5057. doi: 10.1073/pnas.0914266107

Lintelmann, J., Katayama, A., Kurihara, N., Shore, L., and Wenzel, A. (2003). Endocrine disruptors in the environment-(IUPAC Technical Report). Pure Appl. Chem. 75, 631-681. doi: 10.1351/pac200375050631

Liu, S. P., Lorenzen, E. D., Fumagalli, M., Li, B., Harris, K., Xiong, Z. J., et al. (2014). Population genomics reveal recent speciation and rapid evolutionary adaptation in polar bears. Cell 157, 785-794. doi: 10.1016/j.cell.2014.03.054

Macdonald, R. W., Harner, T., and Fyfe, J. (2005). Recent climate change in the Arctic and its impact on contaminant pathways and interpretation of temporal trend data. Sci. Total. Environ. 342, 5-86. doi: 10.1016/j.scitotenv.2004.12.059

Mackenzie, B. R., Payne, M. R., Boje, J., Hoyer, J. L., and Siegstad, H. (2014). A cascade of warming impacts brings bluefin tuna to Greenland waters. Glob. Change Biol. 20, 2484-2491. doi: 10.1111/gcb.12597

Mariussen, E. (2012). Neurotoxic effects of perfluoroalkylated compounds: mechanisms of action and environmental relevance. Arch. Toxicol. 86, 1349-1367. doi: 10.1007/s00204-012-0822-6

McKinney, M. A., Iverson, S. J., Fisk, A. T., Sonne, C., Riget, F. F., Letcher, R. J., et al. (2013). Global change effects on the long-term feeding ecology and contaminant exposures of East Greenland polar bears. Glob. Change Biol. 19, 2360-2372. doi: $10.1111 /$ gcb.12241

McKinney, M. A., Peacock, E., and Letcher, R. J. (2009). Sea ice-associated diet change increases the levels of chlorinated and brominated contaminants in polar bears. Environ. Sci. Technol. 43, 4334-4339. doi: 10.1021/es900471g
McNabb, F. M. A. (1995). Thyroid-hormones, their activation, degradation and effects on metabolism. J. Nutr. 125, S1773-S1776.

Mendizabal, I., Keller, T. E., Zeng, J., and Soojin, V. Y. (2014). Epigenetics and evolution. Integr. Comp. Biol. 54, 31-42. doi: 10.1093/icb/icu040

Mill, J., and Petronis, A. (2008). Pre- and peri-natal environmental risks for attention-deficit hyperactivity disorder (ADHD): the potential role of epigenetic processes in mediating susceptibility. J. Child Psychol. Psychiatry 49, 1020-1030. doi: 10.1111/j.1469-7610.2008.01909.x

Moe, S. J., De Schamphelaere, K., Clements, W. H., Sorensen, M. T., Van Den Brink, P. J., and Liess, M. (2013). Combined and interactive effects of global climate change and toxicants on populations and communities. Environ. Toxicol. Chem. 32, 49-61. doi: 10.1002/etc.2045

Molnar, P. K., Derocher, A. E., Klanjscek, T., and Lewis, M. A. (2011). Predicting climate change impacts on polar bear litter size. Nat. Commun. 2:186. doi: $10.1038 /$ ncomms 1183

Molnar, P. K., Derocher, A. E., Thiemann, G. W., and Lewis, M. A. (2010). Predicting survival, reproduction and abundance of polar bears under climate change. Biol. Conserv. 143, 1612-1622. doi: 10.1016/j.biocon.2010.04.004

Molnar, P. K., Derocher, A. E., Thiernann, G. W., and Lewis, M. A. (2014) Predicting survival, reproduction and abundance of polar bears under climate change (vol 143, pg 1612, 2010). Biol. Conserv. 177, 230-231. doi: 10.1016/j.biocon.2014.07.001

Noyes, P. D., McElwee, M. K., Miller, H. D., Clark, B. W., Van Tiem, L. A., Walcott, K. C., et al. (2009). The toxicology of climate change: environmental contaminants in a warming world. Environ. Int. 35, 971-986. doi: 10.1016/j.envint.2009.02.006

Olsen, G. H., Mauritzen, M., Derocher, A. E., Sormo, E. G., Skaare, J. U., Wiig, O., et al. (2003). Space-use strategy is an important determinant of PCB concentrations in female polar bears in the barents sea. Environ. Sci. Technol. 37, 4919-4924. doi: 10.1021/es034380a

Oskam, I. C., Ropstad, E., Dahl, E., Lie, E., Derocher, A. E., Wiig, Ø., et al. (2003). Organochlorines affect the major androgenic hormone, testosterone, in male polar bears (Ursus maritimus) at Svalbard. J. Toxicol. Environ. Health 66A, 2119-2139. doi: 10.1080/15287390390211342

Oskam, I. C., Ropstad, E., Lie, E., Derocher, A. E., Wiig, O., Dahl, E., et al. (2004). Organochlorines affect the steroid hormone cortisol in free-ranging polar bears (Ursus maritimus) at Svalbard, Norway. J. Toxicol. Environ. Health 67A, 959-977. doi: 10.1080/15287390490443731

Pertoldi, C., Sonne, C., Dietz, R., Schmidt, N. M., and Loeschcke, V. (2009). Craniometric characteristics of polar bear skulls from two periods with contrasting levels of industrial pollution and sea ice extent. J. Zool. 279, 321-328. doi: 10.1111/j.1469-7998.2009.00625.x

Pilsner, J. R., Lazarus, A. L., Nam, D. H., Letcher, R. J., Sonne, C., Dietz, R., et al. (2010). Mercury-associated DNA hypomethylation in polar bear brains via the LUminometric Methylation Assay: a sensitive method to study epigenetics in wildlife. Mol. Ecol. 19, 307-314. doi: 10.1111/j.1365-294X.2009. 04452.x

Polischuk, S. C., Norstrom, R. J., and Ramsay, M. A. (2002). Body burdens and tissue concentrations of organochlorines in polar bears (Ursus maritimus) vary during seasonal fasts. Environ. Pollut. 118, 29-39. doi: 10.1016/S02697491(01)00278-0

Ramsay, M. A., and Hobson, K. A. (1991). Polar bears make little use of terrestrial food webs - evidence from stable-carbon isotope analysis. Oecologia 86, 598-600. doi: 10.1007/BF00318328

Regehr, E. V., Hunter, C. M., Caswell, H., Amstrup, S. C., and Stirling, I. (2010). Survival and breeding of polar bears in the southern Beaufort Sea in relation to sea ice. J. Anim. Ecol. 79, 117-127. doi: 10.1111/j.1365-2656.2009.01603.x

Riget, F., Bossi, R., Sonne, C., Vorkamp, K., and Dietz, R. (2013). Trends of perfluorochemicals in Greenland ringed seals and polar bears: indications of shifts to decreasing trends. Chemosphere 93, 1607-1614. doi: 10.1016/j.chemosphere.2013.08.015

Roberge, J. M. (2014). Using data from online social networks in conservation science: which species engage people the most on Twitter? Biodiv. Conserv. 23 , 715-726. doi: 10.1007/s10531-014-0629-2

Rodier, P. M. (1995). Developing brain as a target of toxicity. Environ. Health Perspect. 103, 73-76. doi: 10.1289/ehp.95103s673

Schiedek, D., Sundelin, B., Readman, J. W., and Macdonald, R. W. (2007). Interactions between climate change and contaminants. Mar. Pollut. Bull. 54, 1845-1856. doi: 10.1016/j.marpolbul.2007.09.020 
Shope, R. E. (1992). "Impacts of global climate change on human health: spread of infectious disease," in Global Climate Change: Implications, Challenges and Mitigation Measures, eds S. K. Majumdar, L. S. Kalkstein, B. Yarnal, E. W. Miller, L. M. Rosenfeld, and P. Easton (Harrisburg, PA: The Pennsylvania Academy of Science), 263-370.

Simon, E., Van Velzen, M., Brandsma, S. H., Lie, E., Loken, K., De Boer, J., et al. (2013). Effect-directed analysis to explore the polar bear exposome: identification of thyroid hormone disrupting compounds in plasma. Environ. Sci. Technol. 47, 8902-8912. doi: 10.1021/es401696u

Skaare, J. U., Bernhoft, A., Wiig, O., Norum, K. R., Haug, E., Eide, D. M., et al. (2001). Relationships between plasma levels of organochlorines, retinol and thyroid hormones from polar bears (Ursus maritimus) at Svalbard. J. Toxicol. Environ. Health 62A, 227-241. doi: 10.1080/009841001459397

Sonne, C. (2010). Health effects from long-range transported contaminants in Arctic top predators: an integrated review based on studies of polar bears and relevant model species. Environ. Int. 36, 461-491. doi: 10.1016/j.envint.2010.03.002

Sonne, C., Leifsson, P. S., Dietz, R., Born, E. W., Letcher, R. J., Hyldstrup, L., et al. (2006). Xenoendocrine pollutants may reduce size of sexual organs in East Greenland polar bears (Ursus maritimus). Environ. Sci. Technol. 40, 5668-5674. doi: 10.1021/es060836n

Stirling, I., and Derocher, A. E. (2012). Effects of climate warming on polar bears: a review of the evidence. Glob. Change Biol. 18, 2694-2706. doi: 10.1111/j.13652486.2012.02753.x

Thiemann, G. W., Iverson, S. J., and Stirling, I. (2008). Polar bear diets and arctic marine food webs: insights from fatty acid analysis. Ecol. Monogr. 78, 591-613. doi: 10.1890/07-1050.1

Unep/Amap. (2011). Climate Change and POPs: Predicting the Impacts. Report of the UNEP/AMAP Epert Group. Geneva: Secretariat of the Stockholm Convention.

Valdimarsson, H., Astthorsson, O. S., and Palsson, J. (2012). Hydrographic variability in Icelandic waters during recent decades and related changes in distribution of some fish species. Ices J. Mar. Sci. 69, 816-825. doi: 10.1093/icesjms/ fss 027

Villanger, G. D., Jenssen, B. M., Fjeldberg, R. R., Letcher, R. J., Muir, D. C. G., Kirkegaard, M., et al. (2011). Exposure to mixtures of organohalogen contaminants and associative interactions with thyroid hormones in East Greenland polar bears (Ursus maritimus). Environ. Int. 37, 694-708. doi: 10.1016/j.envint.2011.01.012
Voltura, M. B., and French, J. B. (2000). Effects of dietary polychlorinated biphenyl exposure on energetics of white-footed mouse, Peromyscus leucopus. Environ. Toxicol. Chem. 19, 2757-2761. doi: 10.1002/etc.5620191121

Vos, J. G., Dybing, E., Greim, H. A., Ladefoged, O., Lambre, C., Tarazona, J. V., et al. (2000). Health effects of endocrine-disrupting chemicals on wildlife, with special reference to the European situation. Crit. Rev. Toxicol. 30, 71-133. doi: 10.1080/10408440091159176

Weber, D. S., De Groot, P. J. V., Peacock, E., Schrenzel, M. D., Perez, D. A., Thomas, S., et al. (2013). Low MHC variation in the polar bear: implications in the face of Arctic warming? Anim. Conserv. 16, 671-683. doi: 10.1111/acv.12045

Wingfield, J. C. (2008). Comparative endocrinology, environment and global change. Gen. Comp. Endocrinol. 157, 207-216. doi: 10.1016/j.ygcen.2008.04.017

Wirgin, I., Roy, N. K., Loftus, M., Chambers, R. C., Franks, D. G., and Hahn, M. E. (2011). Mechanistic basis of resistance to PCBs in Atlantic tomcod from the Hudson River. Science 331, 1322-1325. doi: 10.1126/science.1197296

Zala, S. M., and Penn, D. J. (2004). Abnormal behaviours induced by chemical pollution: a review of the evidence and new challenges. Anim. Behav. 68, 649-664. doi: 10.1016/j.anbehav.2004.01.005

Conflict of Interest Statement: The authors declare that the research was conducted in the absence of any commercial or financial relationships that could be construed as a potential conflict of interest.

Received: 01 December 2014; accepted: 05 February 2015; published online: 24 February 2015.

Citation: Jenssen BM, Villanger GD, Gabrielsen KM, Bytingsvik J, Bechshoft T, Ciesielski TM, Sonne C and Dietz R (2015) Anthropogenic flank attack on polar bears: interacting consequences of climate warming and pollutant exposure. Front. Ecol. Evol. 3:16. doi: 10.3389/fevo.2015.00016

This article was submitted to Interdisciplinary Climate Studies, a section of the journal Frontiers in Ecology and Evolution.

Copyright (c) 2015 Jenssen, Villanger, Gabrielsen, Bytingsvik, Bechshoft, Ciesielski, Sonne and Dietz. This is an open-access article distributed under the terms of the Creative Commons Attribution License (CC BY). The use, distribution or reproduction in other forums is permitted, provided the original author(s) or licensor are credited and that the original publication in this journal is cited, in accordance with accepted academic practice. No use, distribution or reproduction is permitted which does not comply with these terms. 